\title{
Cardiorenal Syndrome in Acute Coronary Disease: A Current Perspective
}

\author{
Hedgar Berty Gutiérrez*, Yenisey Arteaga Concepción, Cristians Auza-Santivañez \\ Intensive Care Department, University Clinical-Surgical Hospital "Miguel Enríquez”, Havana, Cuba \\ Email address: \\ hedgar@infomed.sld.cu (H. B. Gutiérrez) \\ ${ }^{*}$ Corresponding author \\ To cite this article: \\ Hedgar Berty Gutiérrez, Yenisey Arteaga Concepción, Cristians Auza-Santivañez. Cardiorenal Syndrome in Acute Coronary Disease: A \\ Current Perspective. Cardiology and Cardiovascular Research. Vol. 3, No. 3, 2019, pp. 52-54. doi: 10.11648/j.ccr.20190303.12
}

Received: June 29, 2019; Accepted: August 4, 2019; Published: September 3, 2019

\begin{abstract}
Acute coronary disease is one of the leading causes of death in the world. Currently $20-30 \%$ of these patients have acute renal failure forming part of the cardiorenal syndrome. Studies show that the evaluation of renal function through the estimated glomerular filtration rate (eGFR) is related to mortality in patients with cardiovascular disease, with greater precision in eGFR Chronic Kidney Disease Epidemiology Collaboration. Therefore, it is considered an immediate, easy and useful marker for the initial evaluation of patients with acute coronary disease.
\end{abstract}

Keywords: Acute Coronary Syndrome, Glomerular Filtration, Acute Renal Failure

\section{Editorial}

Ischemic heart disease is one of the most prevalent diseases in Western societies, rising, along with the rest of vascular diseases, as the leading cause of death in the developed world. Its presentation as an acute coronary syndrome (ACS) is of particular importance, both because of its morbidity and mortality and because of the large amount of economic, human and healthcare resources that it carries with it $[1,2]$.

There are multiple factors that relate an unfavorable prognosis in patients with cardiovascular disease. One of these factors is renal function, which in recent decades has become more evident the importance of its correct evaluation, especially as a result of studies that have shown that this direct relationship between renal function and cardiovascular events already appears in phases of moderate renal dysfunction, and even mild [1, 2]. Heart failure and cardiogenic shock as a complication of an ACS often coexist with renal dysfunction, defining it as cardiorenal syndrome (CRS) [3-5]. CRS type 1 is determined by an acute deterioration in heart and kidney function initiated by cardiac damage and has prognostic implications in ACS [5, 6]. The main mechanism involved is related to the drop in minute volume that, in addition to systemic hemodynamic disturbances, alters renal perfusion with the consequent decrease in the glomerular filtration rate [7, 8].

Therefore, the accurate assessment of renal function allows early identification of patients at high risk of cardiovascular events, in order to improve their prognosis through early intervention in diagnosis and treatment. In addition, it makes possible the close monitoring of certain interventions such as the adjustment of drugs and the prevention of nephrotoxicity by various agents in high-risk patients. A poor estimate of renal function can lead to a patient not receiving cardioprotective treatment appropriate to their risk, which leads to an increase in mortality [9].

\section{Methods to Evaluate Renal Function}

Currently, serum creatinine is not considered to be an adequate method to identify acute modification of renal function, since its concentrations may be affected by various factors (muscle mass, sex, race, type of feeding), in addition to others related to the own filtration of creatinine, such as tubular secretion, extrarenal production and excretion [10, 11]. For this reason, the role of biomarkers such as neutrophil gelatinase-associated lipocalin (NGAL), renal injury molecule 1 (KIM-1), N-acetyl- $\beta$-D-glucosaminidase (NAG) and cystatin $\mathrm{C}$, are being investigated to assess its usefulness in the detection of acute kidney injury [10].

Cystatin $\mathrm{C}$ is an inhibitor of the cysteine protease, which is 
synthesized by nucleated cells that are filtered in the glomerulus and reabsorbed in the proximal tubule. In patients with extreme body mass indexes, it indicates the true glomerular filtration rate, since it is not affected by muscle mass. Blood levels are detected early before creatinine levels, which is why it is considered a good marker of early kidney injury [11]. Lassus et al, they showed in their study that the increase in cystatin C levels greater than or equal to $0.3 \mathrm{mg} / \mathrm{L}$ was associated with high in-hospital mortality, which is why cystatin $\mathrm{C}$ is considered a potent marker of early acute kidney injury detection and of prognosis in the acute CRS. One drawback is its cost [10].

There are other proposed methods to know the renal function, within which the estimation formulas of the glomerular filtration are the most used in the usual clinical practice due to their relative simplicity. However, its accuracy is not constant in all scenarios and situations continue to arise in which we do not have a reliable method to know the actual degree of renal deterioration of the patient [9]. In fact, in critical patients these formulas have not been studied the same level as in the chronic, it is even suggested that it does not have the same validity due to possible variations in renal function in short periods of time [12].

Despite this, there are a series of studies in which the decrease in estimated glomerular filtration rate (eGFR) is statistically related to the increase in mortality in patients with acute myocardial infarction (AMI). In the study Valsartan in Acute Myocardial Infarction Trial (VALIANT) that included patients with ventricular dysfunction or heart failure after an AMI. All major cardiovascular events, such as total cardiovascular mortality, AMI, heart failure and stroke, were closely related to the degree of renal dysfunction. The incidence of these events doubled or tripled in patients with glomerular filtration $<45 \mathrm{~mL} / \mathrm{min} / 1.73 \mathrm{~m}^{2}$ compared to those with a glomerular filtration rate $>75 \mathrm{~mL} / \mathrm{min} / 1.73 \mathrm{~m}^{2}$ [13]. In the Survival and Ventricular Enlargement study (SAVE), with a similar design, the same results were obtained [14].

According to the latest studies reviewed in the literature, the eGFR Chronic Kidney Disease Epidemiology Collaboration (CKD-EPI) has shown greater accuracy in relation to the Cockcroft-Gaul (CG) and the Modification of Diet in Renal Disease (MDRD4), which it may be related to the fact that the eGFR (CG) depends on the weight or ideal weight estimates, being able to complicate the calculation and the presentation of the results. With respect to eGFR (MDRD4) both in its full and abbreviated form, easily obtainable laboratory data are used, but systematically underestimate the glomerular filtration rate when serum creatinine concentrations are very high, which can lead to misdiagnosis [15]. Gutiérrez HB and colleagues in a study conducted with 295 patients admitted to an ICU with a diagnosis of AMI found that the distribution of eGFR was lower in patients who died in relation to survivors, with a good predictive capacity, but with greater precision in eGFR (CK-EPI) with an area under the ROC curve 0.980 (95\% CI: 0.965-0.995) $(\mathrm{p}<0.0001)[2]$.

With regard to early prognostic stratification, we should point out that only renal function is evaluated as a risk factor in the GRACE study model [16] and in the risk score of the CADILLAC study [17], while in others as used as the TIMI [18] scale it is not any reference is made.

\section{Conclusions}

The assessment of renal function provides useful and very valuable information for the initial assessment of patients with acute coronary disease. Any decrease in the glomerular filtration rate reflects an increase in the probability of death, with greater accuracy with the eGFR (CK-EPI). It is, therefore, a marker of immediate, easy and available in all health centers.

\section{References}

[1] Parra Fuertes PJ, de la Fuente SI. Síndrome coronario agudo sin elevación persistente del segmento ST. En: Montejo CJ, de Lorenzo GA, Marco P, Ortiz C. Manual de medicina intensiva. $5^{\text {ta }}$ edición. España: Elsevier; 2017. p. 105-109.

[2] Gutiérrez HB, Benítez FDM (2018) Valor pronóstico de la función renal a corto plazo en pacientes con infarto agudo de miocardio. Revista Colombiana de Cardiología 25: 26-32.

[3] Rodríguez-Jiménez AE, Negrín-Valdés T, Cruz-Inerarity H, Machural-de la Torre PJ. Síndrome cardiorrenal como predictor de mortalidad intrahospitalaria en el síndrome coronario agudo con elevación del segmento ST. Clínica e Investigación en Arteriosclerosis. 2018; 30 (4): 163-9.

[4] Górriz Teruel JL, Beltrán Catalán S. Valoración de afección renal, disfunción renal aguda e hiperpotasemia por fármacos usados en cardiología y nefrotoxicidad por contrastes. Rev Esp Cardiol. 2011; 64: 1182-92.

[5] Grodin JL. Hemodynamically, the kidney is at the heart of cardiorenal syndrome. CLEVELAND CLINIC 9500 EUCLID AVE, CLEVELAND, OH 44106 USA; 2018.

[6] Di Lullo L, Bellasi A, Russo D, Cozzolino M, Ronco C. Cardio-renal acute kidney injury: Epidemiology, presentation, causes, pathophysiology and treatment. Int J Cardiol. 2017; 227: $143-50.5$.

[7] Hanada S, Takewa Y, Mizuno T, Tsukiyan T, Taenaka Y, Tatsumi E, et al. Effect of the technique for assisting renal blood circula-tion on ischemic kidney in acute cardiorenal syndrome. J ArtifOrgans. 2012; 15: 140-5.

[8] Lobo Márquez LL, de la Serna F. Síndrome cardiorrenal. Rev Fed Arg Cardiol. 2013; 42: 88-95.

[9] Flores Blanco JP. Papel Pronóstico de Nuevos Métodos de Valoración de la Función Renal en Insuficiencia Cardiaca Aguda y Síndrome Coronario Agudo sin elevación del Segmento ST [Tesis Doctoral]. España: Universidad de Murcia; 2016.

[10] Mora SD, Dávila EZ, Silva EN, Mesquita ET, Martins WdA, Villacorta Junior H. Síndrome cardio-renal tipo 1: Mecanismos fisiopatológicos y papel de los nuevos biomarcadores. Insuficiencia cardíaca. 2016; 11 (1): 55-62.

[11] Tan K, Sethi S. Biomarkers in cardiorenal syndromes. TranslRes 2014; 164 (2): 122-34. 
[12] Seller Pérez G, Herrera Gutiérrez ME, Arias Verdú MD, De la Torre Prados MV, Cota Delgado. Fisiopatología de la insuficiencia renal aguda. Lesión renal en el paciente crítico. En: Cárdenas Cruz A, Roca Guiseris J, editores. Tratado de Medicina Intensiva. Barcelona: Elsevier; 2017. p. 395-9.

[13] Anavekar NS, McMurray JJ, Velazquez EJ, Solomon SD, Kober L, Rouleau JL, White HD, et al. Relation between renal dysfunction and cardiovascular outcomes after myocardial infarction. N Engl J Med 2004; 351: 1285-1295.

[14] Jose P, Skali H, Anavekar N, Tomson C, Krumholz HM, Rouleau JL, et al. Increase in creatinine and cardiovascular risk in patients with systolic dysfunction after myocardial infarction. J Am Soc Nephrol 2006; 17: 2886-2891.

[15] Landry DW, Bazari H. Aproximación al paciente con enfermedad renal. En: Goldman-Cecil. Tratado de medicina interna + Expert Consult. 25 Edición. Elsevier: España, 2017; 114: 728-36.

[16] Eagle KA, Lim MJ, Dabbous OH, Pieper KS, Goldberg RJ van de Werf $F$, et al. A validated prediction model for all forms of acute coronary syndrome: estimating the risk of 6month postdischarge death in an international registry. GRACE Investigators. JAMA. 2004; 291: 2727-33.

[17] Halkin A, Singh M, Nikolsky E, et al. Prediction of mortality after primary percutaneous coronary intervention for acute myocardial infarction: the CADILLAC risk score. J Am Coll Cardiol 2005; 45 (9): 1397-405.

[18] Sánchez A, Pou M, Leiro R, López Gómez D, Martínez Ruiz M. D, Saurina A, et al. El grado de insuficiencia renal como predictor de mortalidad tras un síndrome coronario agudo. Nefrología 2009; 29 (1): 53-60. 